\title{
F7 Gene
}

National Cancer Institute

\section{Source}

National Cancer Institute. F7 Gene. NCI Thesaurus. Code C28469.

This gene plays an essential role in the maintenance of cellular homeostasis. 